Article

\title{
Effects of Blueberry and Black Carrot Extracts Addition on Antioxidant Properties and Protein-Precipitating Capacity of Ultrasound-Treated Cider
}

\author{
Boris Brezan ${ }^{1}$, Carmen Liliana Bădărău ${ }^{2, *}$ and Alexandru Woinaroschy ${ }^{1, *(D)}$ \\ 1 Deptment of Chemical and Biochemical Engineering, University POLITEHNICA of Bucharest, \\ 060042 Bucharest, Romania; borisalexid@yahoo.com \\ 2 Deptment of Engineering and Food and Tourism Management, Faculty of Food and Tourism, \\ Transilvania University Brasov, 500014 Brasov, Romania \\ * Correspondence: carmen.badarau@unitbv.ro (C.L.B.); a_woinaroschy@chim.upb.ro (A.W.); \\ Tel.: +40-730-594-687 or +40-743-234-344 (C.L.B.); +40-744-984-792 (A.W.)
}

Received: 29 April 2020; Accepted: 3 July 2020; Published: 10 July 2020

check for updates

\begin{abstract}
The results presented in this study highlight the level of total phenolic content (TPC), total flavonoid content (TFC) and protein-precipitating capacity (PPC) correlated with the antioxidant capacity of new cider varieties enriched with valuable bio compounds by the addition of blueberry and black carrot extracts. The cider variants were treated with ultrasound (constant frequency of $20 \mathrm{kHz}$ ) at $20 \%, 30 \%$ and $40 \%$ amplitude (A) for two, five or seven minutes. TPC determination was performed by Folin-Ciocâlteu method and TFC was determined by an aluminum chloride colorimetric method. The antioxidant capacity was determined by ferric-reducing antioxidant power assay (FRAP), ABTS (2,2'-azino-bis(3-ethylbenzothiazoline-6-sulfonic acid)) assay and DPPH (2,2-diphenyl-1-picrylhydrazyl) radical scavenging activity. The results showed that the antioxidant performance indicators (FRAP, ABTS and DPPH) were positively correlated with the TPC and TFC of the ultrasound-treated cider variants, suggesting that the content of these bio compounds may be improved by the treatments applied. The highest mean values for TPC and TFC were found in the cider variant enriched with black carrot extract $(0.3 \%, v / v)$, subsequently ultrasound-treated (A20\%, five minutes) Conclusively, the extracts used in this study could improve the antioxidant capacity of the cider, especially in case of variants ultrasound-treated.
\end{abstract}

Keywords: cider; black carrot extracts; blueberry extracts; total phenolic content; total flavonoid content; antioxidant capacity

\section{Introduction}

At the present, there is a remarkable global interest to identify and analyze antioxidant compounds from different food sources [1]. Many studies have revealed that these phytochemicals may prevent the development of diabetes and cardiovascular diseases, having favorable impacts on cardiometabolic health, including lowering blood pressure, improving lipid profiles and decreasing markers of inflammation $[2,3]$. Antioxidant compounds can prevent these diseases by reducing or inhibiting the adverse effects of free radicals. These radicals are very reactive and can attack biologically relevant molecules, leading to cell damage [2]. Consequently, there has been an increasing interest in determining the antioxidant potential of natural products such as phenolic compounds $[2,4,5]$.

Between the phenolic compounds, anthocyanin pigments and flavonoids $[3,6]$ are powerful antioxidants that protect cells from various forms of cancer. According to some nutritionists, the human 
food should be rich in antioxidant compounds (especially in the areas with high pollution degree) [7]. The only source for the production of anthocyanin pigments are fruits and vegetables. Anthocyanins are found in blueberries, blackberries, raspberries, cherries, cranberries, black currant, elderberry, eggplant, purple corn, black beans, black carrot and purple potatoes [8,9].

The phenolics contained in cider beverage have a great importance from the sensorial point of view $[10,11]$. They may affect the antioxidant activity, the taste, the visual aspect and the preservation of ciders. No study has been performed on the antioxidant properties and protein-precipitating capacity (PPC) of the ciders enriched with blueberry and black carrot extracts and treated with ultrasounds. The present work is focused to present just these issues, being focused on the effects of the extracts and ultrasounds treatments on the antioxidant properties, TPC (total phenolic compounds), TFC (total flavonoids compounds) and PPC of the cider variants.

The application of ultrasound-assisted extraction for different materials and its opportunities in the food processing industry has proved many advantages $[8,12-19]$. The ultrasound is used in the extraction of biologically compounds from biologic matrices such as in the extraction of phenolics from plants and waste food materials $[17,18]$. Many studies on several bioactive phenolic compounds derived from plants reported the importance of these compounds and the huge demand increase of these natural products on the commercial market $[8,12-16]$. In food processing, ultrasound treatment may be used as an efficient and environmentally friendly treatment for enhancing the nutritional status of products in terms of increasing the bioactive compounds, especially the phenolics [20,21]. It was reported that ultrasound was applied in extraction of plant materials because of increased sugar content, total acid content, phenolics content as well as color density of juices [22]. Moreover, the ultrasound treatment can influence the quality parameters of food products in terms of aromatic profile and sensory properties $[23,24]$. In the last years, many research studies explored the effects of sonication time and amplitude on the total phenolic content in order to optimize the UAE conditions for phenolic compounds [25-28].

In certain conditions, depending to amplitude, frequency, time of treatment, the use of ultrasound is considered a nonthermal processing method, numerous advantages deriving from it (food nutritional quality improvement, thermo sensitive compounds protection, etc.) $[14,19]$. The application of ultrasound in the case of liquids, as in the case of the present work, is based on the phenomenon of cavitation, which involves the formation, development and implosion of bubbles along with the generation and propagation of vibrations in the mass it crosses. The implosion, finally, causes mechanical (turbulent, shear), thermal and also chemical effects [19].

The experimental studies of this research were focused on the following aspects:

- to evaluate the effects of several ultrasound treatments (different amplitudes and time) on TPC, TFC, antioxidant power and protein precipitation capacity of cider enriched with black carrot and blueberry extracts;

- to evaluate the antioxidant capacity of the cider variants using: FRAP (ferric-reducing antioxidant power) assay, ABTS (2,2'-azino-bis(3-ethylbenzothiazoline-6-sulfonic acid)) assay and DPPH (2,2-diphenyl-1-picrylhydrazyl) radical scavenging activity. These assays were chosen because they work under different mechanisms: FRAP and DPPH methods use electron transfer mechanism, while the ABTS method uses both hydrogen atom transfer and single electron transfer mechanisms, depending on the antioxidant present [29]. In addition, they are simple and fast, which is very important when many measurements must be made on many samples.

Phenolic compounds also take part in the formation of haze and sediments because of protein-phenolic interactions, which are the most frequent cause of haze in beverages [30]. The PPC was determined in order to study the tendency of the phenolic compounds of ciders to form solid compounds with the proteins contained in them. It was measured following Hagerman's protocol, a robust method that works well with virtually all plant extracts [31] and is still being used today [32]. The presence of some haze and solids is a characteristic of cider and thus, bottles are usually shaken 
before opening to distribute the turbidity evenly. However, excessive haze or solid quantity is negatively perceived by consumers.

The musts were obtained from a single apple variety. After this, the material was enriched with extracts concentrated in antioxidant compounds (obtained in laboratory conditions [33] and ultrasound-treated using different amplitudes values and times). By spontaneous fermentation, 18 experimental variants of ciders (two extracts additions and ultrasounds treatment parameters) were obtained. The evolution of the musts was followed for six months by measuring the mentioned parameters throughout three samplings. This study presents the results of the final products obtained (the last sampling).

The purpose of this study was to estimate the effect of ultrasound treatments and of two natural extracts additions on the level of TPC and TFC on antioxidant activity of different cider variants. In addition, the PPC of the ciders variants was determined because this indicator is one the indicators of the quality of this beverage.

\section{Materials and Methods}

\subsection{Chemicals and Reagents}

Folin-Ciocâlteu reagent, aluminum chloride were purchased from Sigma-Aldrich (St. Louis, MO, USA). DPPH (cat. no. D9132, purity 97\%) and ABTS (cat. no. A1888, purity 98.6\%) were purchased from Sigma-Aldrich (St. Louis, MO, USA). Quercetin dihydrate and gallic acid were purchased from Karl Roth GmbH (Karlsruhe, Germany). Hydrochloric acid, sodium acetate, sodium carbonate, sodium chloride and sodium hydroxide were purchased from POCH BBASIC (Glivice, Poland). Total Antioxidant Status assay kit was obtained from Rel Assay Diagnostics (Gaziantep, Turkey). Albumin from bovine serum (BSA), iron(III) chloride hexahydrate, tannic acid, triethanolamine, 2,4,6-tripyridyl-s-triazine, sodium dodecyl sulfate (SDS), (trans)-ferulic acid, trolox were purchased from Sigma-Aldrich (St. Louis, MO, USA). Solutions were prepared with double-distilled water.

\subsection{Cider Preparation}

The apples used to make cider were from Royal Gala variety, Voineasa origin (Valcea region, Romania, latitude $45^{\circ} 24^{\prime} 56^{\prime \prime} \mathrm{N}$, longitude $23^{\circ} 57^{\prime} 49^{\prime \prime}$ E) harvested in September 2018 from private orchards. The variety of apple used in the study is recognized as a good variant for obtaining apple juices in Romania, given that it has complex organoleptic properties (especially more mild and sweet aroma), comparing to the varieties studied in 2013 season, when another varieties Golden, Jonathan and Renet were used [34]. Fresh apples were crushed with crusher-destemmer (Enoventa Technologies Enologiche, Piazzola sul Brenta, Italy) followed by a pressing process with a hydraulic press machine (L.U.C.M.E. Elettromeccanica, Verona, Italy). Apple must was obtained in three repetitions (30 kg of apples/repetition). The juice was collected into glass containers for starting fermentation. The temperature during fermentation was maintained at $19^{\circ} \mathrm{C}$. Alcoholic and malolactic fermentations took place spontaneously by indigenous microflora. The development of alcoholic fermentation was followed by the decrease in density and the malolactic fermentation by the decrease in malic acid content.

Vitamin C $(0.01 \mathrm{~g} / \mathrm{L})$ was added to the must before starting fermentation. Because of the presence of this compound (that could produce a degradation of the natural yeast present in the crude juice and a delay of the fermentation), it was necessary to use fermentation yeast of exogenous nature, added to the wort after about two days. The Saccharomyces cerevisiae yeast added to the wort had also the role of removing harmful bacteria from the wort (which can affect the taste of the drink). The added yeast was necessary to ensure the start of fermentation, since in some cases the use of addition may lead to the cessation of the activity of indigenous microflora naturally present in the apple must. It was then desired to stop fermentation when the alcoholic concentration reached just over $5 \%$ by volume $(5.13 \% v / v)$. The cider was subsequently racked to remove the sediments and stored at refrigeration 
temperature. Sulfur dioxide $50 \mathrm{ppm}$ was added to each decantation (but not exceeding the total quantity of $\mathrm{SO}_{2} 200 \mathrm{ppm}$ in any cider, by summarizing all additions). Post-fermentation handling is also crucial for cider quality.

\subsection{Extracts Added to the Cider}

The extracts used for improving the antioxidant capacity of the cider were the following:

- black carrot colorant (commercial extract added to the cider variants in proportion of $0.3 \%, v / v$ );

- blueberry extracts (extract obtained in laboratory, added to the cider variants in proportion of $5 \%$, $v / v)$

The black carrot colorants used at industrial level, it is named in international language "colored concentrate black carrot HC red-blue", manufactured by Dohler GMBH company in Darmstadt, Germany.

The blueberry extract was prepared in laboratory, using fruits from plant growing in spontaneous flora (Vaccinium) and 2\% acidulated water as solvent [33]. The citric acid was used for acidification. The fruits samples were freeze-dried with a $0.12 \mathrm{mBa}$ vacuum at $-50{ }^{\circ} \mathrm{C}$ (ScanVac CoolSafe 55-9 Pro freeze dryer, Denmark), ground to a fine powder (using a coffee grinder). After this, the sample was homogenized for $30 \mathrm{~min}$. at a temperature of $30^{\circ} \mathrm{C}$ with the solvent (report sample: solvent $=1: 20$, $w / v)$, using the extraction solid-liquid. This blueberry extract was ultrasound-treated $(200 \mathrm{~mL}$ placed in glass beaker, the ultrasound probe fixed at $35 \mathrm{~mm}$ depth in the mixture, amplitude A20\%, $5 \mathrm{~min}$ ) using a $750 \mathrm{~W}$ ultrasonic processor for small and medium volume applications (VCX 750, Sonics \& Materials, Inc., Newtown, CT, USA) with a $13 \mathrm{~mm}$ probe, at a constant frequency of $20 \mathrm{kHz}$ [33].

Both extracts were added before ultrasound treatments.

\subsection{Ultrasound Treatment of Enriched-Cider Variants}

The cider variants enriched with the extracts were treated with ultrasound (VCX-750, Sonics \& Materials, Inc., Newtown, CT, USA) at $750 \mathrm{~W}$, with constant frequency of $20 \mathrm{kHz}$ at amplitude A20\%, $\mathrm{A} 30 \%$ and $\mathrm{A} 40 \%$ for time periods of 2, 5 or $7 \mathrm{~min}$ using a probe of $19 \mathrm{~mm}$ and a sample of $500 \mathrm{~mL}$ cider. This combination of amplitude and time was established according results of previous study, where a release of antioxidant compounds was obtained [16]. We used low values for amplitude and time for not improving the values of PPC.

\subsection{Sample Preparation for Analysis}

Cider samples of about $200 \mathrm{~mL}$ were taken at the end of alcoholic fermentation (density $\approx 1000 \mathrm{~g} / \mathrm{L}$ ). Each sample was homogenized by manual shaking and degassed by using a stirrer. Immediately afterwards, density and malic acid content were measured. A $100 \mathrm{~mL}$ portion was centrifuged at $8200 \mathrm{rpm}(9000 \times \mathrm{g})$ for $20 \mathrm{~min}$ in a Hettich EBA21 centrifuge (Thermo Fisher Scientific, Walthan, MA, USA). This portion was used for determination TPC, TFC and to perform FRAP, ABTS, DPPH assays and PPC. The sampling procedure described was performed in one day to avoid oxidation of phenolic compounds and continuation of fermentation.

\subsection{Total Phenolic Content (TPC) Analysis}

The TPC was determined spectrophotometrically by Folin-Ciocâlteu method [35] with several modifications. Fifty microliters of samples were mixed with $100 \mu \mathrm{L}$ distilled water in a 96 well flat bottom assay plate (NUNC, Roskilde, Denmark). Fifty microliters Folin-Ciocâlteu reagent was added and mixed for $1 \mathrm{~min}$ in the plate reader (Tecan, Sun Rise ${ }^{\mathrm{TM}}$, software Magellan ${ }^{\mathrm{TM}}$, Männedorf, Switzerland). After $5 \mathrm{~min}, 80 \mu \mathrm{L}$ of a $20 \%$ solution $(w / v)$ of $\mathrm{Na}_{2} \mathrm{CO}_{3}$ were added and mixed; the microplates were shaken for $5 \mathrm{~min}$. in the plate reader. After this, the plates were incubated at room temperature in the dark, agitating at $150 \mathrm{rpm}$ on a MicroPlate Shaker (Biosan PST-60HL-4, Riga, Latvia) for $90 \mathrm{~min}$. The absorbance of the samples was determined at $725 \mathrm{~nm}$ with a spectrophotometer plate reader 
(Tecan, SunRise ${ }^{\mathrm{TM}}$, software Magellan ${ }^{\mathrm{TM}}$, Männedorf, Switzerland). Gallic acid was used as standard and total phenolic content was expressed as milligrams GAE (gallic acid equivalents) per liter of cider.

\subsection{Total Flavonoid Content (TFC) Analysis}

The method is based on a nitration reaction followed by the formation of an aluminum complex which turns to red in a basic medium [36]. The TFC was measured by a colorimetric method [36] with several minor changes [37]. So, in $1.5 \mathrm{~mL}$ tubes, $150 \mu \mathrm{L}$ cider samples were mixed with $600 \mu \mathrm{L}$ distilled water and $45 \mu \mathrm{L}$ sodium nitrite $7.5 \%$. The mixture was left to react for 5 min. A volume of $45 \mu \mathrm{L}$ aluminum chloride $10 \%$ solution was added in the tubes, mixed by inversion and allowed to react for $1 \mathrm{~min}$. Finally, $300 \mu \mathrm{L}$ of a $1 \mathrm{~N}$ sodium hydroxide solution and $360 \mu \mathrm{L}$ distilled water were added, and the tubes were vortex mixed (Vortex TopMix Stirrer, Heidolph ${ }^{\mathrm{TM}}$, Schwabach, Germany). The absorbance at $510 \mathrm{~nm}$ was measured using a spectrophotometer DR2800 (Hach Lange, Loveland, CO, USA). Values of the absorbance samples were interpolated into a least squares regression equation (a 5-point calibration curve with an $\mathrm{R}^{2}$ value of 0.998 ), which was calculated with the absorbance and the corresponding concentration of each quercetin standard [37]. Final results were calculated taking into account the dilution factors applied and were expressed as mg quercetin equivalents $(\mathrm{QE})$ per liter of cider [37].

\subsection{FRAP Assay}

This assay was performed according to the Benzie and Strain procedure [38] using Trolox as a standard instead of ascorbic acid and with some changes to adapt the method to the automatic analyzer. The following solutions were prepared: (a) acetate buffer 300 mM pH 3.6; (b) 2,4,6-tripyridyl-s-triazine $10 \mathrm{mM}$ in $\mathrm{HCl} 40 \mathrm{mM}$; (c) $\mathrm{FeCl}_{3} \cdot 6 \mathrm{H}_{2} \mathrm{O} 20 \mathrm{mM}$; (d) working FRAP reagent prepared at the time of use (mixture of the previous solutions in the ratio of 10:1:1, respectively).

The assay was achieved as follows. Sample or standard $(3 \mu \mathrm{L})$ was mixed with $300 \mu \mathrm{L}$ of working FRAP reagent and absorbance at $600 \mathrm{~nm}$ was measured after $4 \mathrm{~min}$. Trolox standards $(0$ to $5 \mathrm{mmol} / \mathrm{L})$ were used to construct the calibration curve (absorbance versus Trolox mmol/L). Results are given in mmol Trolox Equivalents per liter of cider (mmol TE/L).

\subsection{ABTS Assay}

This assay was measured according to the procedure described by Erel [39] and performed with the Total Antioxidant Status assay kit [40]. The commercial kit provides a $0.4 \mathrm{mmol} / \mathrm{L}$ acetic/acetate buffer solution of pH 5.8 and a $30 \mathrm{mmol} / \mathrm{L}$ solution of ABTS radical cation.

The assay was achieved as follows. Sample or standard $(4 \mu \mathrm{L})$ was mixed with $200 \mu \mathrm{L}$ of acetic/acetate buffer and $25 \mu \mathrm{L}$ of ABTS radical cation reagent and absorbance at $670 \mathrm{~nm}$ was measured after $5 \mathrm{~min}$. Trolox standards ( 0 to $5 \mathrm{mmol} / \mathrm{L}$ ) were used to construct the calibration curve (absorbance versus Trolox mmol/L). Results are given in mmol Trolox Equivalents per liter of cider (mmol TE/L).

\subsection{DPPH Assay}

Volumes $20-\mu \mathrm{L}$ of samples were added to $20 \mathrm{~mL}$ of distilled water in a 96 -well bottom microplate. Two hundred microliters of $120 \mathrm{mg} / \mathrm{L} \mathrm{DPPH} \mathrm{radical} \mathrm{solution} \mathrm{(using} \mathrm{ethanol} \mathrm{as} \mathrm{a} \mathrm{solvent)} \mathrm{was} \mathrm{then}$ added and mixed thoroughly. The absorbance was measured using a plate reader (Tecan, SunRise ${ }^{\mathrm{TM}}$, software Magellan ${ }^{\mathrm{TM}}$, Männedorf, Switzerland) at $515 \mathrm{~nm}$ after keeping the plates in the dark for $30 \mathrm{~min}$. A control with $20 \mu \mathrm{L}$ of ethanol was also included in each plate.

The DPPH radical scavenging activity was calculated with the formula:

$$
\text { DPPH radical inhibition }(\%)=[(\text { A control }- \text { A sample }) / A \text { control }] \times 100
$$

where A control is the absorbance of the control at $515 \mathrm{~nm}$ and A sample is the absorbance of the sample at $515 \mathrm{~nm}$. 


\subsection{1. $P P C$}

According to Hagerman's method [31], the following solutions were prepared: (a) $0.20 \mathrm{M}$ acetate buffer of pH 4.9 in $0.17 \mathrm{M} \mathrm{NaCl}$; (b) $1 \mathrm{mg} / \mathrm{mL}$ bovine serum albumin (BSA) dissolved in the previous buffer; (c) $50 \mathrm{~mL} / \mathrm{L}$ triethanolamine (TEA) in $10 \mathrm{~g} / \mathrm{L}$ sodium dodecyl sulfate (SDS); $0.01 \mathrm{M} \mathrm{FeCl}_{3}$ in $0.01 \mathrm{M} \mathrm{HCl}$. The assay was performed as follows. A total of $2.00 \mathrm{~mL}$ BSA solution was dispensed into $15 \mathrm{~mL}$ centrifuge tubes, and $1 \mathrm{~mL}$ of sample solution was added to it. Both the solutions were mixed immediately and allowed to sit for $24 \mathrm{~h}$ at $4{ }^{\circ} \mathrm{C}$. Then the mixture was centrifuged for $15 \mathrm{~min}$ at $8200 \mathrm{rpm}$ and poured off the supernatant. The pellet was dissolved in $4.00 \mathrm{~mL}$ SDS/TEA solution, followed by the addition of $1.00 \mathrm{~mL} \mathrm{FeCl}_{3}$ solution; the mixture was vortexed immediately. After about $15 \mathrm{~min}$, the absorbance was measured at $510 \mathrm{~nm}$ using a spectrophotometer DR2800 (Hach Lange, Loveland, CO, USA).

\subsection{Statistical Analysis}

Data were performed by using SPSS (statistical package for the social sciences) software and analyzed by ANOVA and Duncan's multiple range test (scored as significant if $p<0.05$ ). It was analyzed the correlation between the variables, using the Pearson correlation coefficients.

\section{Results}

\subsection{Cider Variants and Classification}

The cider experimental variants obtained and tested in this study are presented in Table 1.

Table 1. ID (coding) of the cider variants obtained using the extracts additions and ultrasound treatments.

\begin{tabular}{|c|c|c|c|}
\hline Extracts Added & $\mathrm{A}(\%)$ & Time (min) & ID Cider Variants \\
\hline Black carrot extracts & - & - & $\mathrm{C}$ \\
\hline \multirow[t]{9}{*}{$(0.3 \%, v / v)$} & A20\% & 2 & C202 \\
\hline & & 5 & C205 \\
\hline & & 7 & C207 \\
\hline & $\mathrm{A} 30 \%$ & 2 & C302 \\
\hline & & 5 & C305 \\
\hline & & 7 & C307 \\
\hline & $\mathrm{A} 40 \%$ & 2 & C402 \\
\hline & & 5 & C405 \\
\hline & & 7 & C407 \\
\hline Blueberry extracts & - & - & B \\
\hline \multirow[t]{9}{*}{$(5 \%, v / v)$} & $\mathrm{A} 20 \%$ & 2 & B202 \\
\hline & & 5 & B205 \\
\hline & & 7 & B207 \\
\hline & A30\% & 2 & B302 \\
\hline & & 5 & B305 \\
\hline & & 7 & B307 \\
\hline & $\mathrm{A} 40 \%$ & 2 & B402 \\
\hline & & 5 & B405 \\
\hline & & 7 & B407 \\
\hline Cider without extracts & & & $\mathrm{M}$ \\
\hline
\end{tabular}

According to the English classification of cider apple varieties, they are divided into four groups: bittersharp ( $>4.5 \mathrm{~g} / \mathrm{L}$ malic acid, $>2 \mathrm{~g} / \mathrm{L}$ tannic acid), sharp ( $>4.5 \mathrm{~g} / \mathrm{L}$ malic acid, $<2 \mathrm{~g} / \mathrm{L}$ tannic acid), bittersweet $(<4.5 \mathrm{~g} / \mathrm{L}$ malic acid, $>2 \mathrm{~g} / \mathrm{L}$ tannic acid $)$ and sweet $(<4.5 \mathrm{~g} / \mathrm{L}$ malic acid, $<2 \mathrm{~g} / \mathrm{L}$ tannic 
acid) [41]. All the cider variants obtained in this research were bitter sweet [data not shown]. Compared with the products obtained in 2013 [34], a more aromatic cider variants were obtained.

\subsection{Total Phenolic Content (TPC)}

Table 2 shows the total phenolic content of cider variants analyzed. There were significant differences between the variants, samples enriched with black carrot and treated using the amplitude A20\% having the highest TPC values (from 423.6 to $730.5 \mathrm{mg} \mathrm{GAE} / \mathrm{L}$ ). The lowest TPC was found for the cider samples with blueberry extracts and treated using the highest amplitude A40\% (from 152 to $184 \mathrm{mg}$ GAE/L).

As shown in Figure 1, Tables 2 and 3 the sonication conditions of the cider with extracts added had a significant influence of the TPC.

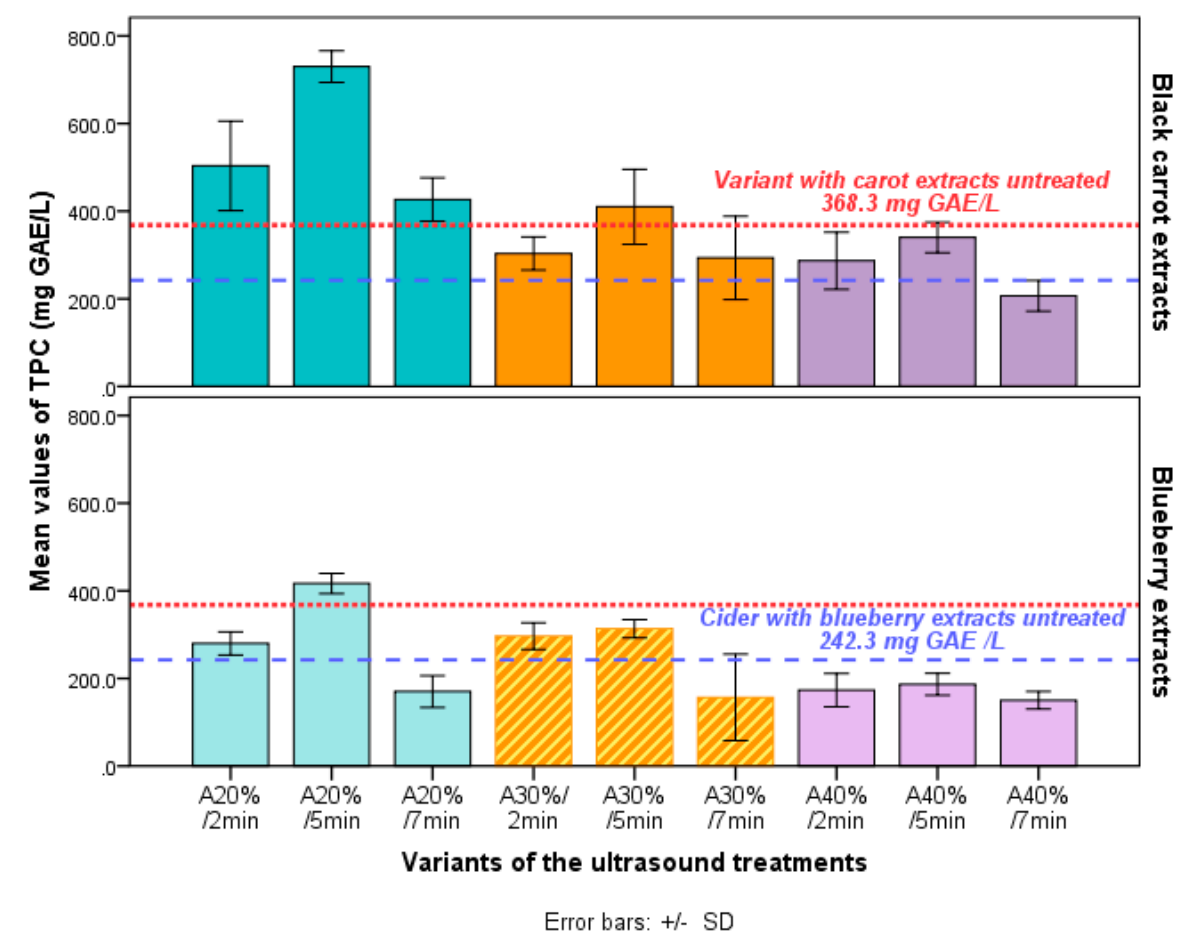

Figure 1. Effects of the ultrasound treatments and of extracts additions (for obtaining cider enriched with antioxidants) on the TPC values (mg GAE/L). Data are means of 3 experiments $(n=3)$. Abbreviations: TPC—-total phenolic content; GAE—gallic acid equivalent; A—amplitude.

The results show that TPC of the cider enriched with black carrot extracts was significant higher $(p<0.05)$ than the cider untreated (Figure 1, Table 3a). It was an increase of TPC values from control M (191.1 $\pm 32.7 \mathrm{mg} \mathrm{GAE} / \mathrm{L})$ for both extracts added (Figure 1, Table 3a).

Regarding the sonication parameters, the highest TPC of the ciders was obtained using amplitude $\mathrm{A} 20 \%$ (Table $3 \mathrm{~b}$ ) and $5 \mathrm{~min}$ as time period. Hence, the ultrasonic treatments using this parameters provide positive improvements such that the controls. The effectiveness of the ultrasound treatments could result from the economical prices of the process (by reducing the amplitude and time periods) and from the improvement of phenolic compound yield.

Similar results (regarding the high value of TPC observed after samples ultrasonic treatments at low values of amplitude) has also been reported by Lieu et al. for grape [42], Adekunte et al. [43] for tomato juice and Bhat et al. [44] for lime juice which presented higher total phenolic compound content after sonication. Phenolic compounds are found in soluble form in the vacuole or bound to the pectin, hemicellulose traces of the wall [45]. It is possible that ultrasound enhances the release of these compounds from the cell wall [46], through the collapse via cavitation in the surroundings 
of colloidal particles [47]. During the cider storage, the senescence and decomposition of the cell structure could take place and thus, free phenolic acids and free amino acids are released, contributing to increasement of total phenolic compounds. This change may be attributed to cell wall degradation caused by microbial growth during first days of storage in control samples.

Table 2. Phenolic content of the cider experimental variants.

\begin{tabular}{cccccc}
\hline & Cod & TPC (mg GAE/L) & \pm & SD & Duncan $^{\mathbf{2}}$ \\
\hline Cider variants & C202 & 503.8 & \pm & 101.9 & $\mathrm{~b}$ \\
with black carrot & C205 & 730.5 & \pm & 38.6 & $\mathrm{a}$ \\
extracts & C207 & 423.6 & \pm & 51.2 & $\mathrm{~b}-\mathrm{c}$ \\
and & C302 & 303.6 & \pm & 35.4 & $\mathrm{~d}-\mathrm{g}$ \\
ultrasound & C305 & 411.0 & \pm & 84.8 & $\mathrm{C}$ \\
treated & C307 & 294.1 & \pm & 91.5 & $\mathrm{~d}-\mathrm{g}$ \\
& C402 & 287.9 & \pm & 68.0 & $\mathrm{~d}-\mathrm{g}$ \\
& C405 & 339.3 & \pm & 36.6 & $\mathrm{c}-\mathrm{e}$ \\
& C407 & 208.5 & \pm & 38.2 & $\mathrm{f}-\mathrm{i}$ \\
\hline Cider variants & B202 & 279.5 & \pm & 25.0 & $\mathrm{~d}-\mathrm{h}$ \\
with blueberry & B205 & 415.6 & \pm & 21.4 & $\mathrm{~b}-\mathrm{C}$ \\
extracts & B207 & 167.6 & \pm & 39.2 & $\mathrm{i}$ \\
and & B302 & 296.5 & \pm & 30.1 & $\mathrm{~d}-\mathrm{g}$ \\
ultrasound & B305 & 312.8 & \pm & 23.9 & $\mathrm{~d}-\mathrm{e}$ \\
treated & B307 & 155.5 & \pm & 95.7 & $\mathrm{i}$ \\
& B402 & 174.3 & \pm & 38.5 & $\mathrm{i}$ \\
& B405 & 184.0 & \pm & 28.8 & $\mathrm{~h}-\mathrm{i}$ \\
& B407 & 152.5 & \pm & 18.0 & $\mathrm{i}$ \\
\hline Controls & M Cider & 191.1 & \pm & 32.7 & $\mathrm{~g}-\mathrm{i}$ \\
untreated & C & 368.3 & \pm & 24.7 & $\mathrm{C}-\mathrm{d}$ \\
& B & 242.3 & \pm & 21.9 &
\end{tabular}

${ }^{1}$ Data are means \pm SD of three experiments $(n=3) .{ }^{2}$ Values with different letters differ significantly by ANOVA and Duncan's test $(p<0.05)$. Abbreviations: TPC-total phenolic content; GAE-gallic acid equivalent; SD-standard deviation.

\subsection{TFC of the Cider Variants}

Figure 2 shows the results of total flavonoid content. Ultrasonic treated samples exhibited higher total flavonoid content values compared to the controls in both case of extracts additions. With the advantage of extracts added (black carrot extracts) the untreated sample had an increase of these compounds, while the variants with blueberry extracts added presented slight variability.

Compared with the control C $(30.42 \pm 3.154 \mathrm{mg}$ QE/L), the highest values for TFC in case of the ciders enriched with black carrot were obtained for the lowest amplitude of ultrasonic sonication treatments (A20\%) (43.82 $\pm 7.843 \mathrm{mg} \mathrm{QE} / \mathrm{L}$ for $2 \mathrm{~min}, 45.13 \pm 1.655 \mathrm{mg}$ QE/L for $5 \mathrm{~min}$ and, respectively $40.62 \pm 1.450 \mathrm{mg} \mathrm{QE} / \mathrm{L}$ for $5 \mathrm{~min}$ ) (Figure 2, Table 4).

Regarding the samples with blueberry extracts, only two treatments variants lead to highest values of TFC compared with the control B. These values were obtained using the lowest amplitude $\mathrm{A} 20 \%$ for $2 \mathrm{~min}(31.99 \pm 3.387 \mathrm{mg} \mathrm{QE} / \mathrm{L})$ and for $5 \mathrm{~min}(35.85 \pm 1.618 \mathrm{mg} \mathrm{QE} / \mathrm{L})$.

The results show that TFC of the cider enriched with black carrot extracts was significantly higher than the variant $C$ (Table 5). It was a significant increase of TFC values and for variant C305 if the comparison was made using the experience mean. 
Table 3. Influences of the (a) extracts additions, (b) sonication amplitude and (c) sonication times on TPC.

\begin{tabular}{ccc}
\hline $\begin{array}{c}\text { Experimental Conditions } \\
\text { (Extracts, Treatments) }\end{array}$ & $\begin{array}{c}\text { TPC } \\
\text { (mg GAE/L) }\end{array}$ & Duncan $^{\mathbf{1}^{2}}$ \\
\hline a. Extracts added & & \\
\hline Black carrot extracts added and treated & 388.9 & $\mathrm{a}$ \\
Blueberry extracts added and treated & 298.1 & $\mathrm{a}-\mathrm{b}$ \\
Cider with carrot and untreated(C) & 368.3 & $\mathrm{a}-\mathrm{b}$ \\
Cider with blueberry and untreated(B) & 243.3 & $\mathrm{a}-\mathrm{b}$ \\
Cider (M) & 193.1 & $\mathrm{~b}$ \\
\hline LSD 5\%= 5.3 & & \\
\hline b. Amplitude & & $\mathrm{a}$ \\
\hline A20\% & 421.1 & $\mathrm{~b}$ \\
A30\% & 295.6 & $\mathrm{~b}$ \\
A $40 \%$ & 223.9 & $\mathrm{~b}$ \\
$0 \%$ & 268.9 & \\
\hline LSD $5 \%=46.4$ & & $\mathrm{a}-\mathrm{b}$ \\
\hline c. Times (min) & & $\mathrm{a}$ \\
\hline 2.0 & 304.2 & $\mathrm{~b}$ \\
\hline 7.0 & 396.7 & 235.8 \\
0.0 & 268.9 & \\
\hline
\end{tabular}

$\operatorname{LSD} 5 \%=38.7$

${ }^{1}$ Data are means \pm SD of three experiments $(n=3) .{ }^{2}$ Values with different letters differ significantly by ANOVA and Duncan's test $(p<0.05)$. Abbreviations: TPC—-total phenolic content; GAE—gallic acid equivalent; SD—standard deviation; LSD $5 \%$-least significant difference at a significance $p<0.05$.

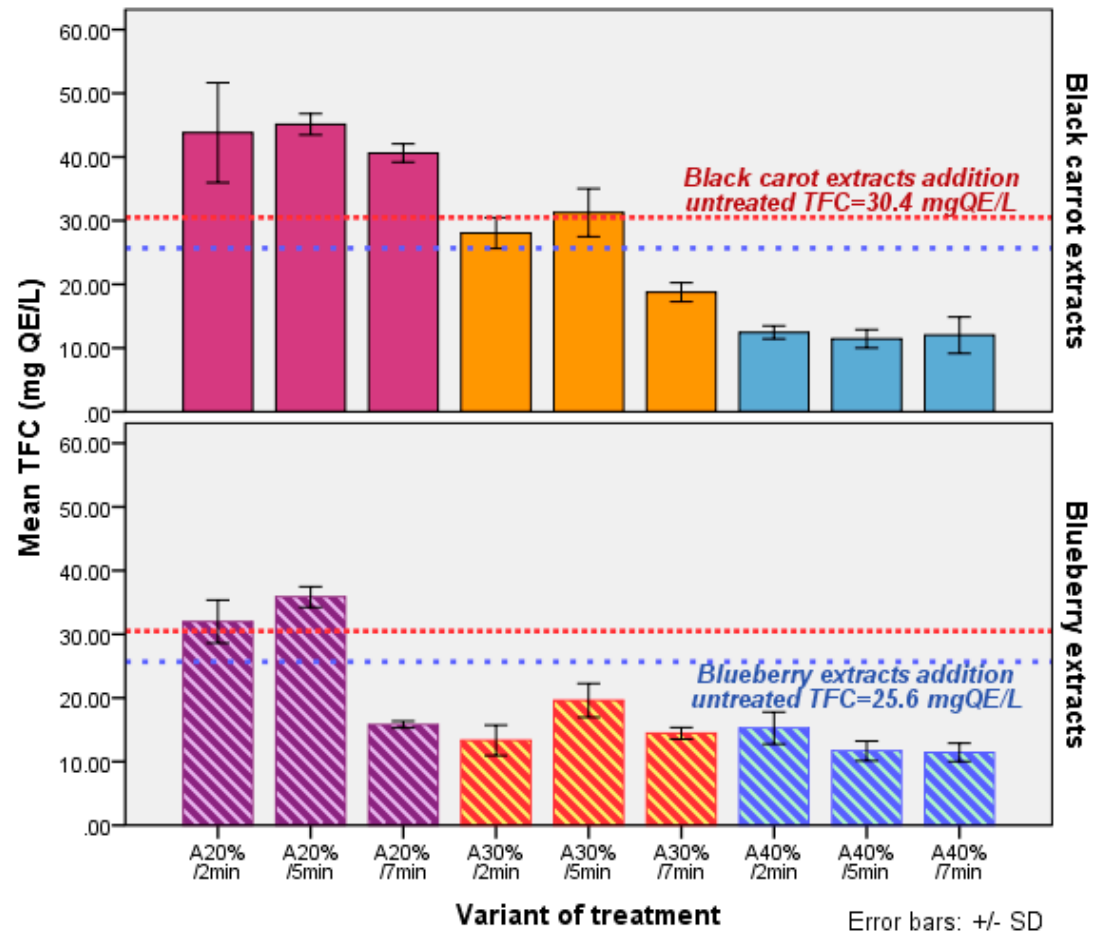

Figure 2. Effects of the ultrasound treatments and of extracts additions (for obtaining cider enriched with antioxidants) on the TFC values (mg QE/L). Data are means of 3 experiments $(n=3)$. Abbreviations: TFC - total flavonoids content; $\mathrm{QE}$ - quercetin equivalent; A-amplitude of ultrasounds. 
Table 4. Flavonoid contents of the cider experimental variants.

\begin{tabular}{|c|c|c|c|c|c|}
\hline & Cod & TFC (mg QE/L) ${ }^{1}$ & \pm & SD & Duncan $^{2}$ \\
\hline \multirow{9}{*}{$\begin{array}{l}\text { Cider variants } \\
\text { with black carrot } \\
\text { extracts } \\
\text { and } \\
\text { ultrasound } \\
\text { treated }\end{array}$} & C202 & 43.82 & \pm & 7.843 & a \\
\hline & C205 & 45.13 & \pm & 1.655 & a \\
\hline & C207 & 40.62 & \pm & 1.450 & a \\
\hline & C302 & 28.05 & \pm & 2.437 & $c-d$ \\
\hline & C305 & 31.28 & \pm & 3.776 & $b-c$ \\
\hline & C307 & 18.76 & \pm & 1.490 & $e-f$ \\
\hline & C402 & 12.45 & \pm & 1.022 & $\mathrm{~g}-\mathrm{h}$ \\
\hline & C405 & 11.45 & \pm & 1.442 & $\mathrm{~h}$ \\
\hline & C407 & 12.02 & \pm & 2.853 & $\mathrm{~h}$ \\
\hline \multirow{9}{*}{$\begin{array}{l}\text { Cider variants } \\
\text { with blueberry } \\
\text { extracts } \\
\text { and } \\
\text { ultrasound } \\
\text { treated }\end{array}$} & B202 & 31.99 & \pm & 3.387 & $b-c$ \\
\hline & B205 & 35.85 & \pm & 1.618 & $\mathrm{~b}$ \\
\hline & B207 & 15.82 & \pm & 0.535 & e-h \\
\hline & B302 & 13.34 & \pm & 2.400 & $g-h$ \\
\hline & B305 & 19.62 & \pm & 2.664 & e \\
\hline & B307 & 14.45 & \pm & 0.907 & $\mathrm{f}-\mathrm{h}$ \\
\hline & B402 & 15.28 & \pm & 2.520 & e-h \\
\hline & B405 & 11.68 & \pm & 1.543 & $\mathrm{~h}$ \\
\hline & B407 & 11.45 & \pm & 1.442 & $\mathrm{~h}$ \\
\hline \multirow{3}{*}{$\begin{array}{l}\text { Controls } \\
\text { untreated }\end{array}$} & M Cider & 17.42 & \pm & 0.858 & $\mathrm{e}-\mathrm{g}$ \\
\hline & C & 30.42 & \pm & 3.514 & c \\
\hline & B & 25.68 & \pm & 1.371 & d \\
\hline
\end{tabular}

${ }^{1}$ Data are means \pm SD of three experiments $(n=3) .{ }^{2}$ Values with different letters differ significantly by ANOVA and Duncan's test $(p<0.05)$. Abbreviations:-TFC—-total flavonoids content; QE-quercetin equivalent; SD—standard deviation.

Table 5. Influences of the treatments and extracts addition on total flavonoids content of the cider experimental variants enriched with antioxidants.

\begin{tabular}{cccccccc}
\hline Cider Variant & TFC & DifM & Sig & DifB & Sig & DifC & Sig \\
\hline C405 & 11.5 & -11.50 & ooo & -14.23 & ooo & -19.0 & ooo \\
B407 & 11.5 & -11.50 & ooo & -14.23 & ooo & -19.0 & ooo \\
B405 & 11.7 & -11.27 & ooo & -14.00 & ooo & -18.7 & ooo \\
C407 & 12.0 & -10.93 & ooo & -13.66 & ooo & -18.4 & ooo \\
C402 & 12.5 & -10.50 & ooo & -13.23 & ooo & -18.0 & ooo \\
B302 & 13.3 & -9.61 & ooo & -12.34 & ooo & -17.1 & ooo \\
B307 & 14.4 & -8.50 & ooo & -11.23 & ooo & -16.0 & ooo \\
B402 & 15.3 & -7.67 & oo & -10.40 & ooo & -15.1 & ooo \\
B207 & 15.8 & -7.13 & oo & -9.86 & ooo & -14.6 & ooo \\
M Cider & 17.4 & -5.53 & o & -8.26 & ooo & -13.0 & ooo \\
C307 & 18.8 & -4.18 & & -6.91 & oo & -11.7 & ooo \\
B305 & 19.6 & -3.33 & & -6.06 & oo & -10.8 & ooo \\
Mean experience & 22.9 & 0.00 & & -2.73 & & -7.5 & oo \\
B untreated & 25.7 & 2.73 & & 0.00 & & -4.7 & o \\
C302 & 28.0 & 5.10 & $*$ & 2.37 & & -2.4 & \\
C untreated & 30.4 & 7.47 & $* *$ & 4.74 & & 0.0 & \\
C305 & 31.3 & 8.33 & $* * *$ & 5.60 & $*$ & 0.9 & \\
B202 & 32.0 & 9.04 & $* * *$ & 6.31 & $* *$ & 1.6 & \\
B205 & 35.8 & 12.90 & $* * *$ & 10.17 & $* * *$ & 5.4 & $*$ \\
C207 & 40.6 & 17.67 & $* * *$ & 14.94 & $* * *$ & 10.2 & $* * *$ \\
C202 & 43.8 & 20.87 & $* * *$ & 18.14 & $* * *$ & 13.4 & $* * *$ \\
C205 & 45.1 & 22.18 & $* * *$ & 19.45 & $* * *$ & 14.7 & $* * *$ \\
\hline LSD 5\% 4.58 & LSD 1\% & 6.13 & & LSD 0.1\% & 8.10 & & \\
\hline
\end{tabular}

Comparison of the means with the controls with extracts additions and untreated. Abbreviations:-TFC - total flavonoid content; DifM — difference to the mean experience; DifB — difference to B untreated; DifC—-difference to C untreated; Sig.-_significance; LSD 5\%-least significant difference for $p<0.05$; LSD $1 \%$-least significant difference for $p<0.01$; LSD $0.1 \%$ - least significant difference for $p<0.001$; " $\mathrm{o}$ "—-difference significant negative; "oo" — difference distinct significant negative; "ooo"—-difference very significant negative; "*"-difference significant positive; “***”-difference distinct significant positive; “***”—difference very significant positive; Data are means \pm SD of 3 experiments $(n=3)$. 


\subsection{PPC of the Cider Variants}

In this research, for estimate the PPC, we used only the values of absorbance values (at $510 \mathrm{~nm}$ ) of samples treated as described in the previous paragraph. The values of this parameter are presented in Table 6 and Figure 3. They are correlated with the values of TPC and TFC. Because of the treatments, the cider variants with the highest TPC and TFC values had higher values of PPC.

Many papers were published about the interaction between phenolics and proteins to form haze or sediments in beverages, mostly beers, wines and fruit juices, including apple juices [30,48-51]. According to them, protein-phenolic interactions are the most frequent cause of hazes in beverages. Flavonols-especially catechins and procyanidins-are considered as main contributors to haze.

However, there is a single work that tries to find relations between haze or solids formed in ciders and individual phenolics [52]. Milet et al. (2017) reported that the phenolics found in haze were, in decreasing concentration order, chlorogenic acid $>4$ - $p$-coumaroylquinic acid $>$ phloridzin $>$ phloretin 2'-O-xyloglucoside > epicatechin. The authors are not sure about the procyanidins content. Apparently, phenolics in ciders do not have the same behavior pattern as reported in other beverages, including apple juices. In the next work of the same team about this subject [53], they demonstrated that not procyanidins, but their oxidized derivatives are responsible for haze formation.

Table 6. Precipitation capacity of the cider variants with extracts added and ultrasound-treated.

\begin{tabular}{|c|c|c|c|c|c|}
\hline & Cod & $\operatorname{PPC}(A 510 \mathrm{~nm})^{1}$ & \pm & SD & Duncan $^{2}$ \\
\hline Cider variants & C202 & 1.033 & \pm & 0.074 & $\mathrm{~b}$ \\
\hline with black carrot & C205 & 1.404 & \pm & 0.054 & $\mathrm{a}$ \\
\hline extracts & C207 & 1.089 & \pm & 0.128 & $\mathrm{~b}$ \\
\hline and & C302 & 1.129 & \pm & 0.134 & $b$ \\
\hline \multirow{5}{*}{$\begin{array}{l}\text { ultrasound } \\
\text { treated }\end{array}$} & C305 & 1.033 & \pm & 0.074 & $\mathrm{~b}$ \\
\hline & C307 & 1.077 & \pm & 0.226 & $\mathrm{~b}$ \\
\hline & C402 & 0.510 & \pm & 0.130 & $d-f$ \\
\hline & C405 & 0.587 & \pm & 0.074 & $c-f$ \\
\hline & C407 & 0.440 & \pm & 0.044 & $f-g$ \\
\hline Cider variants & B202 & 0.677 & \pm & 0.038 & $c-d$ \\
\hline with blueberry & B205 & 0.698 & \pm & 0.136 & c \\
\hline extracts & B207 & 0.659 & \pm & 0.039 & $\mathrm{c}-\mathrm{e}$ \\
\hline and & B302 & 0.491 & \pm & 0.041 & $e-g$ \\
\hline \multirow{5}{*}{$\begin{array}{l}\text { ultrasound } \\
\text { treated }\end{array}$} & B305 & 0.560 & \pm & 0.120 & $c-f$ \\
\hline & B307 & 0.246 & \pm & 0.083 & $\mathrm{~h}$ \\
\hline & B402 & 0.326 & \pm & 0.058 & $g-h$ \\
\hline & B405 & 0.262 & \pm & 0.052 & $\mathrm{~h}$ \\
\hline & B407 & 0.184 & \pm & 0.060 & $\mathrm{~h}$ \\
\hline \multirow{3}{*}{$\begin{array}{l}\text { Controls } \\
\text { untreated }\end{array}$} & M Cider & 0.736 & \pm & 0.120 & c \\
\hline & C & 0.959 & \pm & 0.039 & b \\
\hline & B & 0.660 & \pm & 0.115 & e-g \\
\hline
\end{tabular}

${ }^{1}$ Data are means \pm SD of three experiments $(n=3) .{ }^{2}$ Values with different letters differ significantly by ANOVA and Duncan's test $(p<0.05)$. Abbreviations: PPC—-protein precipitation capacity; A $510 \mathrm{~nm}$-absorbance at $510 \mathrm{~nm}$; LSD 5\%-least significant difference for $p<0.05$. 


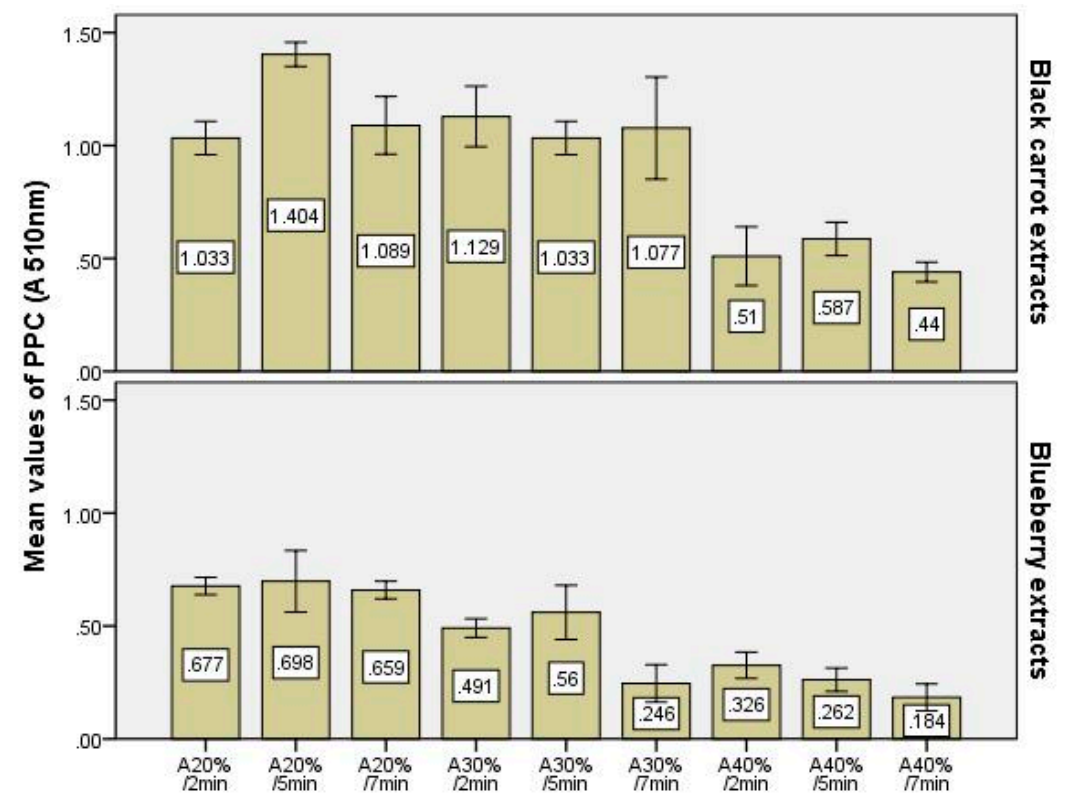

Variants of ultrasound treatments

Error bars: +/- SD

Figure 3. Effects of the ultrasound treatments and of extracts additions (for obtaining cider enriched with antioxidants) on the protein precipitation capacity $(A 510 \mathrm{~nm})$. Data are means of 3 experiments $(\mathrm{n}=3)$. Abbreviations: PPC-protein precipitation capacity; A $510 \mathrm{~nm}$-absorbance value at $510 \mathrm{~nm}$; A-amplitude of ultrasounds.

\subsection{Antioxidant Capacity of the Cider Variants}

Table 7 shows the antioxidant capacity of the experimental cider variants (evaluated using FRAP, ABTS and DPPH assay). As shown in this table, the values of FRAP, ABTS and DPPH inhibition were significantly different between the ciders tested $(p<0.05)$.

Regarding the antioxidant capacity expressed using all the assay, there were significantly differences between the variants, the cider with black carrot colorant ultrasound-treated (A20\%, 5 min (C205) having the highest values $(14.69 \pm 0.09-\mathrm{mmol} \mathrm{TE} / \mathrm{L}$ for FRAP assay, $25.79 \pm 0.89-\mathrm{mmol} \mathrm{TE} / \mathrm{L}$ for ABTS assay, respectively $65.35 \% \pm 2.59 \%$ for DPPH radicals inhibition $\%$ ). The lowest values for all these antioxidant assay were found for the cider with blueberry extracts added and treated at the highest amplitude and time period (B407), (2.16 $\pm 0.18-\mathrm{mmol} \mathrm{TE} / \mathrm{L}$ for FRAP assay, $5.48 \pm 1.75-\mathrm{mmol} \mathrm{TE} / \mathrm{L}$ for ABTS assay, respectively $25.94 \% \pm 4.309 \%$ for DPPH radicals inhibition $\%$ ).

The antioxidant capacity reported in our study are higher than those reported by Picinelli (2009) [54]. In comparison with other alcoholic and non-alcoholic beverages, the antioxidant power of many cider variants obtained using the extracts and ultrasound treatments was more power full, as you can see in Table 8 .

In Table 8, only ABTS values are displayed in order to make comparisons, since they are given in most of the articles. FRAP values appear less often. The antioxidant activity range of the ciders between $5.48 \pm 0.89$ and $25.79 \pm 1.75-\mathrm{mmol} \mathrm{TE} / \mathrm{L}$, lies over that the treatments and extracts added and is a little higher to that of red wines. This is an important fact because the great antioxidant activity of wines is often quoted as a beneficial aspect. Moreover, the antioxidant activity of our ciders variants is greater than that of other alcoholic beverages like beer, Cognac, Armagnac and rum. With respect to non-alcoholic beverages, the antioxidant activity of the ciders is similar to that of coffee and is greater than that of tea (excepting the variant B407), orange juice, olive oil, sunflower oil and cola. The comparison with orange juice is particularly interesting because this drink is always quoted as model of healthy and antioxidant beverage. 
Table 7. Antioxidant capacity of the cider experimental variants enriched with antioxidants extracts and ultrasound-treated.

\begin{tabular}{|c|c|c|c|c|c|c|c|c|c|c|}
\hline & ID & $\begin{array}{c}\text { FRAP } \\
(\mathrm{mmol} \mathrm{TE} / \mathrm{L})\end{array}$ & $\pm \mathrm{SD}$ & Duncan & $\begin{array}{c}\text { ABTS } \\
(\mathrm{mmol} \mathrm{TE} / \mathrm{L})\end{array}$ & $\pm \mathrm{SD}$ & Duncan & DPPH\%inh & $\pm \mathrm{SD}$ & Duncan \\
\hline Black & C202 & 11.02 & \pm 0.33 & $\mathrm{~b}$ & 19.13 & \pm 0.70 & $c-d$ & 61.90 & \pm 3.570 & $\mathrm{a}-\mathrm{b}$ \\
\hline Carrot & C205 & 14.69 & \pm 0.09 & a & 25.79 & \pm 0.89 & $\mathrm{a}$ & 65.35 & \pm 2.587 & $\mathrm{a}$ \\
\hline extracts & C207 & 9.76 & \pm 0.09 & $\mathrm{~d}$ & 10.58 & \pm 0.05 & $g-h$ & 53.94 & \pm 7.377 & $b-e$ \\
\hline addition & С 302 & 10.23 & \pm 0.34 & c & 17.45 & \pm 0.93 & $\mathrm{e}$ & 55.44 & \pm 6.648 & $a-d$ \\
\hline and & C 305 & 7.75 & \pm 0.18 & $\mathrm{f}$ & 21.57 & \pm 1.06 & $\mathrm{~b}$ & 59.28 & \pm 1.108 & $a-c$ \\
\hline \multirow{4}{*}{$\begin{array}{l}\text { ultrasound } \\
\text { treated }\end{array}$} & C307 & 4.02 & \pm 0.23 & $i-j$ & 15.84 & \pm 1.13 & $\mathrm{e}$ & 43.43 & \pm 5.561 & $\mathrm{e}-\mathrm{h}$ \\
\hline & C402 & 3.10 & \pm 0.12 & $\mathrm{~m}$ & 9.57 & \pm 0.58 & $g-h$ & 46.41 & \pm 2.453 & $d-g$ \\
\hline & C405 & 3.37 & \pm 0.19 & $1-\mathrm{m}$ & 7.60 & \pm 0.89 & $\mathrm{i}$ & 44.99 & \pm 5.685 & $\mathrm{~d}-\mathrm{g}$ \\
\hline & C407 & 2.51 & \pm 0.09 & $\mathrm{n}$ & 7.40 & \pm 0.49 & i & 37.24 & \pm 6.416 & $\mathrm{f}-\mathrm{i}$ \\
\hline \multirow{9}{*}{$\begin{array}{l}\text { Blueberry } \\
\text { extracts } \\
\text { addition } \\
\text { and } \\
\text { ultrasound }\end{array}$} & B202 & 8.52 & \pm 0.23 & e & 13.36 & \pm 0.52 & $\mathrm{f}$ & 51.10 & \pm 8.628 & $a-d$ \\
\hline & B205 & 9.44 & \pm 0.19 & $\mathrm{~d}$ & 18.41 & \pm 1.48 & $c-d$ & 56.29 & \pm 2.884 & b-e \\
\hline & B207 & 5.63 & \pm 0.26 & $\mathrm{~g}$ & 10.96 & \pm 0.82 & $g-h$ & 45.34 & \pm 3.208 & $\mathrm{~d}-\mathrm{g}$ \\
\hline & B302 & 3.80 & \pm 0.34 & $\mathrm{j}-\mathrm{k}$ & 7.40 & \pm 0.49 & $i-j$ & 45.91 & \pm 4.309 & $\mathrm{~d}-\mathrm{g}$ \\
\hline & B305 & 4.43 & \pm 0.23 & $\mathrm{~h}-\mathrm{i}$ & 9.09 & \pm 0.65 & $\mathrm{~h}$ & 48.40 & \pm 1.398 & $c-f$ \\
\hline & B307 & 3.57 & \pm 0.04 & $\mathrm{k}-\mathrm{l}$ & 5.80 & \pm 0.79 & $\mathrm{j}$ & 29.21 & \pm 7.221 & $i-j$ \\
\hline & B402 & 3.16 & \pm 0.27 & $\mathrm{~m}$ & 6.48 & \pm 0.60 & $\mathrm{i}-\mathrm{j}$ & 23.67 & \pm 5.685 & $\mathrm{j}$ \\
\hline & B405 & 2.34 & \pm 0.07 & $\mathrm{n}$ & 7.64 & \pm 0.22 & $\mathrm{i}$ & 29.50 & \pm 4.560 & $i-j$ \\
\hline & B407 & 2.16 & \pm 0.18 & $\mathrm{n}$ & 5.48 & \pm 1.75 & j & 25.94 & \pm 4.309 & $\mathrm{j}$ \\
\hline \multirow{3}{*}{$\begin{array}{l}\text { Controls } \\
\text { untreated }\end{array}$} & $\mathrm{M}$ & 3.28 & \pm 0.10 & $1-m$ & 6.60 & \pm 0.32 & $i-j$ & 26.58 & \pm 8.805 & $i-j$ \\
\hline & C & 5.91 & \pm 0.16 & $\mathrm{~g}$ & 14.88 & \pm 0.84 & $\mathrm{e}$ & 46.23 & \pm 3.375 & $d-g$ \\
\hline & B & 4.31 & \pm 0.14 & $h-i$ & 9.57 & \pm 0.58 & $\mathrm{~g}-\mathrm{h}$ & 36.60 & \pm 1.303 & $g-i$ \\
\hline & $\begin{array}{l}\text { LSD } \\
5 \%\end{array}$ & & 0.34 & & 1.43 & & & 8.54 & & \\
\hline
\end{tabular}

Data are means \pm SD of three experiments $(\mathrm{n}=3)$. Values with different letters differ significantly by ANOVA and Duncan's test $(p<0.05)$. Abbreviations: DPPH-2,2-diphenyl-1-picrylhydrazyl, FRAP-ferric reducing antioxidant power, ABTS-2,2'-azino-bis(3-ethylbenzothiazoline-6-sulfonic acid); LSD 5\%-least significant difference for $p<0.05$. 
Table 8. Capacity of several alcoholic and non-alcoholic beverages.

\begin{tabular}{cc}
\hline Other Beverages & ABTS (mmol TE/L) \\
\hline Red wine [55-58] & $2.3-25.2$ \\
Rosé wine [56,58] & $1.5-3.2$ \\
White wine [57,58] & $0.1-1.9$ \\
Beers from all over the world [59] & $0.6-2.0$ \\
Cognac [60] & $0.7-4.9$ \\
Armagnac [55] & $0.6-1.2$ \\
Rum [56] & $<0.1$ \\
Cola [55,56] & $<0.1$ \\
Coffee filter coffees from all over the world (100 g/L) [61] & $7.8-12.3$ \\
Tea infusion, 5 min in boiling water (15 g/L) [62] & $0.8-6.3$ \\
Orange juice (fresh juices of Italian oranges) [63] & $0.7-7.1$ \\
Olive oil (Italian oils) [55,56] & $0.4-1.8$ \\
Sunflower oil [55,56] & $0.1-1.2$ \\
\hline
\end{tabular}

Evaluation of antioxidant activities of a selected antioxidant needs multiple test systems. DPPH free radical is a stable group which is broadly used in evaluating the scavenging activity of antioxidant on the free radical. In DPPH assay, the DPPH radical inhibition\% by antioxidants was attributed to their hydrogen-donating capability. Figure $4 \mathrm{~A}$ shows the scavenging activities for DPPH radicals, the DPPH free radical inhibition $\%$ increased from $37.24 \% \pm 6.416 \%$ to $65.9 \% \pm 2.587 \%$ for the cider enriched with black carrot extracts and from $25.94 \% \pm 4.309 \%$ to $56.29 \% \pm 2.884 \%$ for the variants with blueberry extracts.

The results indicate that the extracts added have good percent inhibition activity on the DPPH radicals, but lower than that of the other radicals used in our research (Table 7).

As shown in Figure 4, the ultrasonic sonication conditions of the cider with extracts added had a significant influence of the antioxidant activity tested by FRAP and ABTS assay.

The results show that a good antioxidant capacity is preferably to obtain using a lower amplitude (in our case A20\%) and a period time $5 \mathrm{~min}$ and this is most probably due to the high sensitivity of phenolic compounds to ultrasonic amplitude power. This observation is in agreement with the previous finding by Nayak and Rastogi (2011) [64] where they found that an amplitude of $10 \%-14 \%$ was optimum for improving the antioxidant capacity.

In our study, the TPC and TFC values were correlated with the antioxidant activity estimated using FRAP, ABTS and DPPH inhibition percent. The lowest value of the correlation coefficient $\left(\mathrm{R}^{2}\right)$ was obtained in case of DPPH.

Our study show that the FRAP assay values were good correlated with the TFC $\left(R^{2}=0.873\right)$. In all cases the best correlations were identify in case of TFC, compared with TPC. It is possible that some differences between phenolic content influenced the antioxidant capacity because the complex samples (extracts) could content some phenolic non antioxidants.

A good correlation was found and between TFC and FRAP values $\left(R^{2}=0.873\right)$ and between PPC and ABTS values $\left(R^{2}=0.704\right)$ (Figure 5). Table 9 presents the Pearson correlation coefficients $(p<0.01)$ for the interaction between TPC, TFC, PPC and the antioxidant capacity of the cider variants (expressed by ABTS, FRAP values and DPPH percent inhibition values). The results reveal a positive correlation between the antioxidant activity and all the chemical compounds tested. 
Table 9. Pearson correlation coefficients for the interaction between TPC, TFC, PPC and the antioxidant capacity of the cider variants (expressed by ABTS, FRAP values and DPPH \% inhibition values).

\begin{tabular}{cccccc}
\hline & $\begin{array}{c}\text { TFC } \\
(\mathbf{m g ~ Q E} / \mathbf{L})\end{array}$ & $\begin{array}{c}\text { FRAP } \\
(\mathbf{m m o l} \text { TE/L) }\end{array}$ & $\begin{array}{c}\text { ABTS } \\
(\mathbf{m m o l} \text { TE/L) }\end{array}$ & $\begin{array}{c}\text { DPPH } \\
\text { (\% inhibition) }\end{array}$ & $\begin{array}{c}\text { PPC } \\
\mathbf{( A ~ 5 1 0 ~} \mathbf{~ n m})\end{array}$ \\
\hline TPC (mg GAE/L) & $0.795^{* *}$ & $0.798^{* *}$ & $0.766^{* *}$ & $0.746^{* *}$ & $0.759^{* *}$ \\
TFC (mg QE/L) & & $0.934^{* *}$ & $0.795^{* *}$ & $0.753^{* *}$ & $0.763^{* *}$ \\
FRAP (mmol TE/L) & & & $0.849^{* *}$ & $0.787^{* *}$ & $0.817^{* *}$ \\
ABTS (mmol TE/L) & & & & $0.778^{* *}$ & $0.839^{* *}$ \\
DPPH (\% inhibition) & & & & & $0.776^{* *}$ \\
\hline ** Correlation is significant at the 0.01 level (2-tailed). Number of samples $=54$ Abbreviations: TP_total phenolic
\end{tabular}

** Correlation is significant at the 0.01 level (2-tailed). Number of samples $=54$. Abbreviations: TP-total phenolic content; TF-total flavonoids content; DPPH-2,2-diphenyl-1-picrylhydrazyl; FRAP-ferric reducing antioxidant power; ABTS-2,2'-azino-bis(3-ethylbenzothiazoline-6-sulfonic acid); QE—quercetin equivalent; GAE—gallic acid equivalent; TE-trolox equivalent.

All experiments were used without experimental planning (multivariate). We intend to achieve the optimum condition for obtaining the best cider variant in a next more complex article. Therefore, we could go further in the experiments to optimization the process, we intent to add to the results presented in this study the content of other compounds that gives the nutritional value of our cider variants (vitamin C, tannic acid, malic acid, carbohydrates).
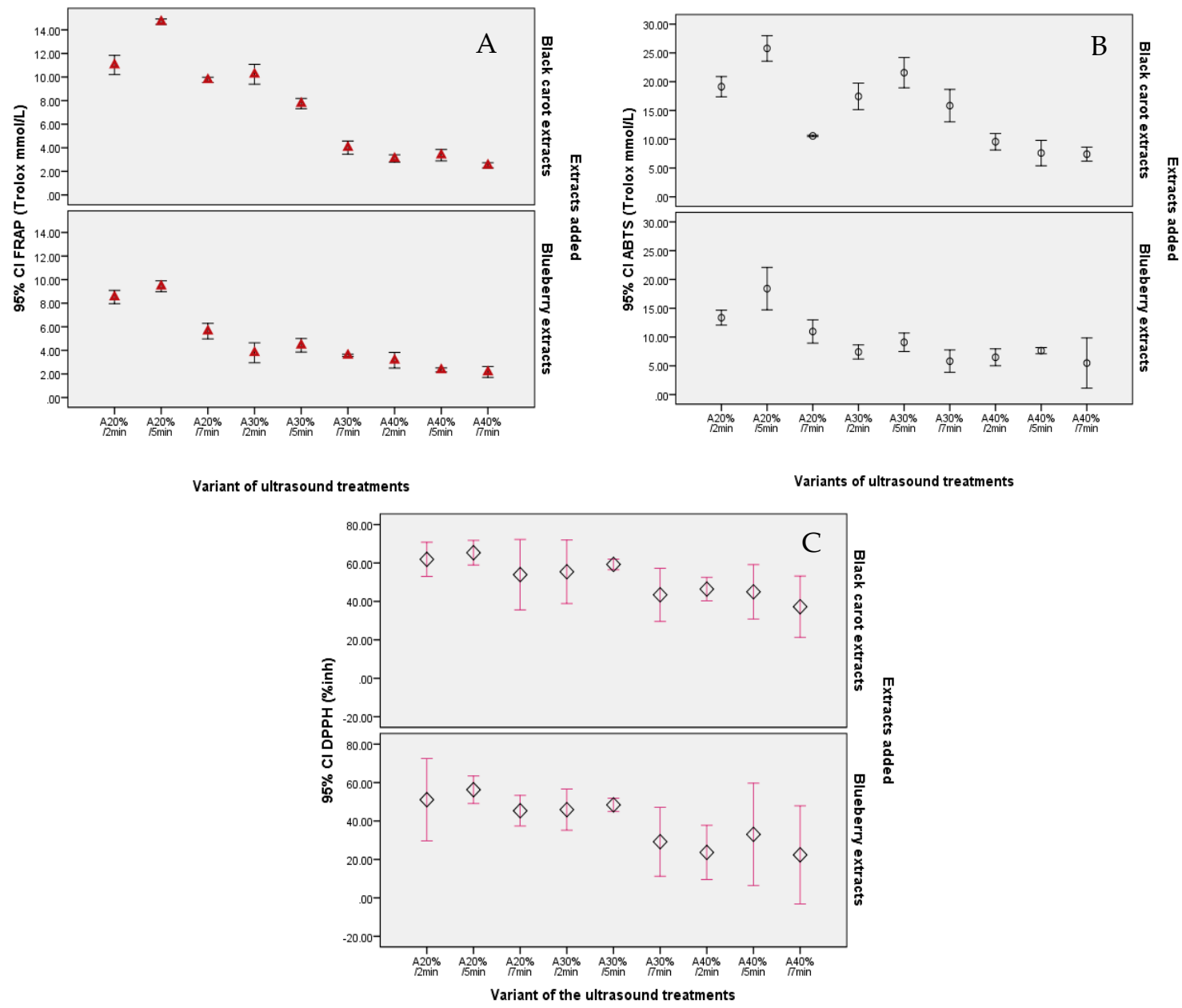

Figure 4. Effects of the ultrasound treatments and of extracts additions (for obtaining cider enriched with antioxidants) on FRAP assay results (mmol TE/L). (A) ABTS assay results (mmol TE/L); (B) DPPH inhibition \%; (C) of the cider variants obtained. Data are means of three experiments $(n=3)$. $\mathrm{CI}-$ confidence intervals of means. 

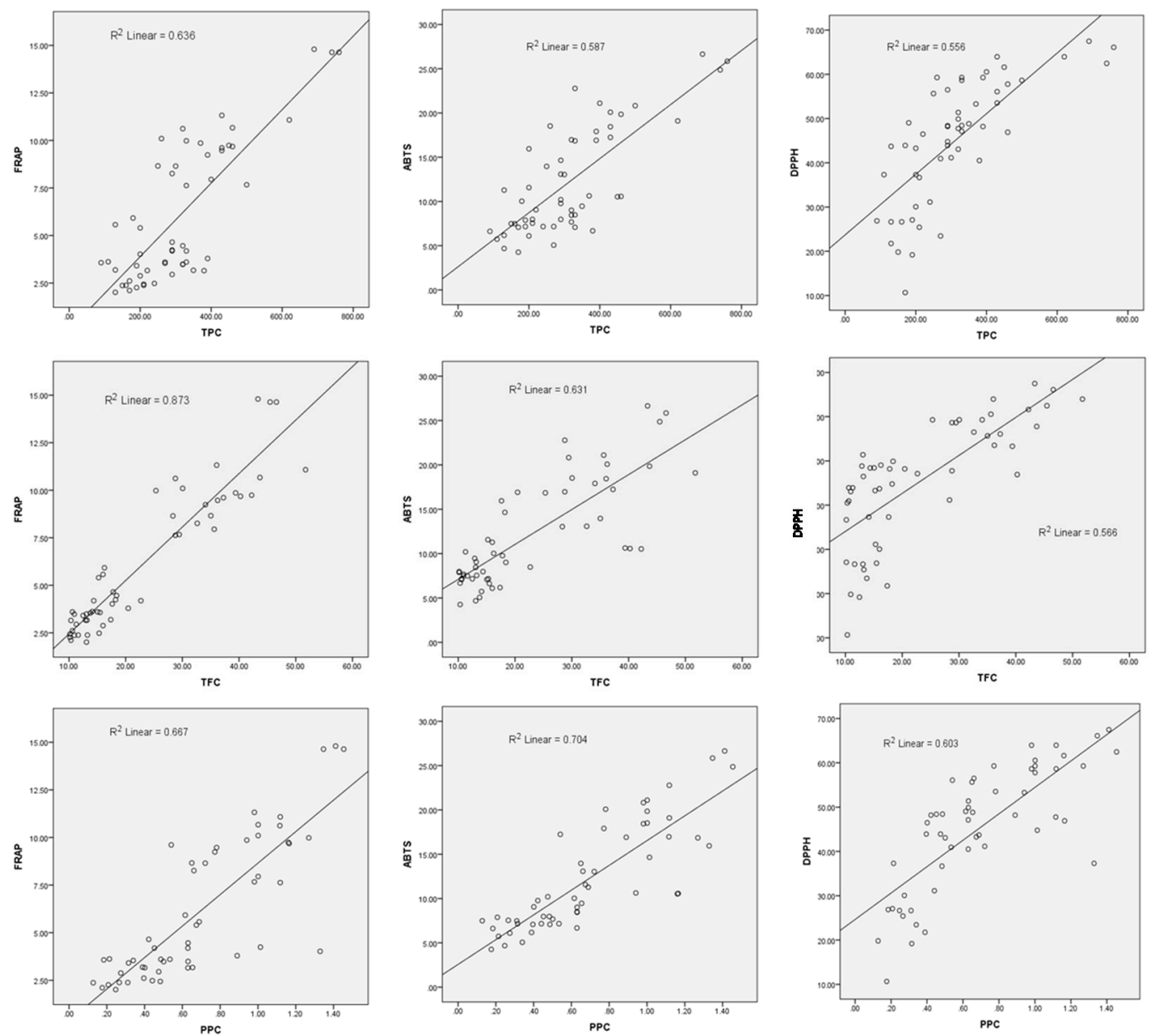

Figure 5. Correlations between the antioxidant capacity assay and total phenolic content, total flavonoid content and protein-precipitating capacity. Abbreviations: TPC—total phenolic content; GAE—gallic acid equivalent; QE-quercetin equivalent; TFC—-total flavonoid content; DPPH-2,2-diphenyl-1-picrylhydrazyl; FRAP-ferric reducing antioxidant power; ABTS-2,2'-azino-bis(3-ethylbenzothiazoline-6-sulfonic acid).

\section{Conclusions}

The results presented in this study highlight the level of total phenolic and flavonoids content correlated with the antioxidant capacity (expressed by three types of assay) of several cider variants enriched by adding extract from black carrot and from blueberry fruits and ultrasonic sonication treated.

The FRAP, ABTS and DPPH scavenging activity is due among others to the content in phenolics and flavonoids (which were detected in significant amount in the variants of cider ultrasonic treated using frequency of $20 \mathrm{kHz}$, amplitude of $20 \%$, time period five minutes). The highest mean values for these compounds were found in cider sampled from variant enriched with black carrot extracts $(0.3 \%$, $v / v)$ treated in the conditions presented above. Regarding the cider enriched with blueberry extracts $(5 \%, v / v)$ the highest values of TPC and TFC values were obtained for the samples treated in similar conditions presented above. Unfortunately, the PPC of the variants very rich in polyphenols had high values and could damage the quality of the ciders. However, the intensive color of these variants cover up the haze of the beverage.

The values of FRAP-, ABTS- and DPPH-scavenging activity were significantly different between the cider variants tested $(p<0.05)$, the variant with the highest TPC and TFC values having the highest percentage of radical inhibition. 
The results indicated that the cider variants enriched using the carrot and blueberry extracts exhibited good antioxidant capacity, similar or highest to that of red wines and greater than that of orange juices.

The cider enriched with antioxidants could contribute to the daily intake of phenolics and flavonoids (phytochemicals with functional and antioxidant potential) and their consumption thereby may have positive effects on the human health. We could go further in the experiments to identify the beneficial compounds "hidden" in the cider variants obtained in our study.

Author Contributions: Conceptualization, A.W., C.L.B.; methodology, A.W., C.L.B. and B.B.; software, A.W., C.L.B.; validation, A.W., C.L.B. and B.B.; formal analysis, C.L.B. and B.B.; investigation, A.W., C.L.B. and B.B.; resources, A.W., C.L.B. and B.B.; data curation, A.W, C.L.B.; writing-original draft preparation, C.L.B. and B.B.; writing-review and editing, A.W.; visualization, A.W., C.L.B. and B.B.; supervision, A.W. All authors have read and agreed to the published version of the manuscript.

Funding: This research received no external funding.

Acknowledgments: The authors would like to thank for the financial support of project 37N/2019 (chemical reagents), for the winery laboratory (extracts, cider variants prepared) and for the biochemistry laboratory (chemical tests) of the Faculty of Food and Tourism, Transylvania University Brasov, Romania. The authors acknowledge the technical support provided by doctoral project of Boris Brezan (PhD supervisor Alexandru Woinaroschy).

Conflicts of Interest: All authors declare no conflicts of interest.

\section{References}

1. Larondelle, Y.; Evers, D.; André, C.M. Dietary Antioxidants and Oxidative Stress from a Human and Plant Perspective: A Review. Curr. Nutr. Food Sci. 2010, 6, 2-12. [CrossRef]

2. Duthie, G.G.; Duthie, S.; Kyle, J.A.M. Plant polyphenols in cancer and heart disease: Implications as nutritional antioxidants. Nutr. Res. Rev. 2000, 13, 79-106. [CrossRef]

3. Otaki, N.; Kimira, M.; Katsumata, S.-I.; Uehara, M.; Watanabe, S.; Suzuki, K. Distribution and Major Sources of Flavonoid Intakes in the Middle-Aged Japanese Women. J. Clin. Biochem. Nutr. 2009, 44, $231-238$. [CrossRef] [PubMed]

4. Cerit, I.; Yildirim, A.; Ucar, M.K.; Demirkol, A.; Cosansu, S.; Demirkol, O. Estimation of antioxidant activity of foods using artificial neural networks. J. Food. Nutr. Res. 2017, 56, 138-148.

5. Parsons, B.J. Antioxidants in Food: The Significance of Characterisation, Identification, Chemical and Biological Assays in Determining the Role of Antioxidants in Food. Foods 2017, 6, 68. [CrossRef] [PubMed]

6. Tsao, R.; Yang, R.; Xie, S.; Sockovie, E.; Khanizadeh, S. Which Polyphenolic Compounds Contribute to the Total Antioxidant Activities of Apple? J. Agric. Food Chem. 2005, 53, 4989-4995. [CrossRef]

7. Damsa, F.; Woinaroschy, A.; Olteanu, G. Quantification of Total Flavonoid and Total Anthocyanin Content from Purple Potato. Rev. Chim. Bucharest Romania 2015, 66, 227.

8. Damşa, F.; Woinaroschy, A.; Olteanu, G.; Bădărău, C.L.; Mărculescu, A. Total monomeric anthocyanin and total flavonoid content of processed purple potato. IJERA 2016, 6, 75-82.

9. Woinaroschy, A.; Damşa, F. Multiobjective Optimization of Total Monomeric Anthocyanins and Total Flavonoids Contents in Ultrasound-Assisted Extraction from Purple Potato Tubers. J. Food Process. Eng. 2016, 40, e12422. [CrossRef]

10. Rodríguez, R.; Picinelli, A.; Suárez, B. Phenolic profile of Asturian (Spain) natural cider. J. Agric. Food Chem. 2006, 54, 120-124.

11. Lea, A.G.; Piggott, J.R. Fermented Beverage Production; Kluwer Academic/Plenum Publishers: New York, NY, USA, 1995; pp. 59-87.

12. Zafra-Rojas, Q.Y.; Cruz-Cansino, N.D.S.; Ramírez-Moreno, E.; Delgado-Olivares, L.; Villanueva-Sánchez, J.; Alanís-García, E. Effects of ultrasound treatment in purple cactus pear (Opuntia ficus-indica) juice. Ultrason. Sonochem. 2013, 20, 1283-1288. [CrossRef]

13. Tiwari, B.K.; O'donnell, C.P.; Patras, A.; Cullen, P.J. Anthocyanin and ascorbic acid degradation in sonicated strawberry juice. J. Agric. Food Chem. 2008, 56, 10071-10077. [CrossRef] [PubMed]

14. Vinatoru, M. An overview of the ultrasonically assisted extraction of bioactive principles from herbs. Ultrason. Sonochem. 2001, 8, 303-313. [CrossRef] 
15. Vilkhu, K.; Mawson, R.; Simons, L.; Bates, D. Applications and opportunities for ultrasound assisted extraction in the food industry-A review. Innov. Food Sci. Emerg. 2008, 9, 161-169. [CrossRef]

16. Cheok, C.Y.; Chin, N.L.; Yusof, Y.A.; Talib, R.A.; Law, C.L. Optimization of total monomeric anthocianin (TMA) and total phenolic compounds (TPC) extractions from mangosteen (Garcinia mangostana Linn.) hull using ultrasonic treatments. Ind. Crop. Prod. 2013, 50, 1-7. [CrossRef]

17. Dolatowski, Z.J.; Stadnik, J.; Stasiak, D. Applications of ultrasound in food technology. Acta Sci. Pol. Technol. Aliment. 2007, 6, 88-99.

18. Dzah, C.S.; Duan, Y.; Zhang, H.; Wen, C.; Zhang, J.; Chen, G.; Ma, H. The effects of ultrasound assisted extraction on yield, antioxidant, anticancer and antimicrobial activity of polyphenol extracts: A review. Food Biosci. 2020, 35, 100547. [CrossRef]

19. Aguilar, K.; Garvín, A.; Ibarz, A.; Augusto, P.E. Ascorbic acid stability in fruit juices during thermosonication. Ultrason. Sonochem. 2017, 37, 375-381. [CrossRef] [PubMed]

20. Wen, C.; Zhang, J.; Zhang, H.; Dzah, C.S.; Zandile, M.; Duan, Y.; Ma, H.; Luo, X. Advances in ultrasound assisted extraction of bioactive compounds from cash crops-A review. Ultrason. Sonochem. 2018, 48, 538-549. [CrossRef] [PubMed]

21. Nadeem, M.; Ubaid, N.; Qureshi, T.M.; Munir, M.; Mehmood, A. Effect of ultrasound and chemical treatment on total phenol, flavonoids and antioxidant properties on carrot-grape juice blend during storage. Ultrason. Sonochem. 2018, 45, 1-6. [CrossRef]

22. Wang, J.; Wang, J.; Ye, J.; Vanga, S.K.; Raghavan, V. Influence of high-intensity ultrasound on bioactive compounds of strawberry juice: Profiles of ascorbic acid, phenolics, antioxidant activity and microstructure. Food Control 2019, 96, 128-136. [CrossRef]

23. Jambrak, A.R.; Šimunek, M.; Petrović, M.; Bedić, H.; Herceg, Z.; Juretić, H. Aromatic profile and sensory characterisation of ultrasound treated cranberry juice and nectar. Ultrason. Sonochem. 2017, 38, 783-793. [CrossRef] [PubMed]

24. Khandpur, P.; Gogate, P. Effect of novel ultrasound based processing on the nutrition quality of different fruit and vegetable juices. Ultrason. Sonochem. 2015, 27, 125-136. [CrossRef] [PubMed]

25. Bouaoudia-Madi, N.; Boulekbache-Makhlouf, L.; Madani, K.; Silva, A.M.S.; Dairi, S.; Oukhmanou-Bensidhoum, S.; Cardoso, S.M. Optimization of Ultrasound-Assisted Extraction of Polyphenols from Myrtus communis L. Pericarp. Antioxidants 2019, 8, 205. [CrossRef] [PubMed]

26. Annegowda, H.V.; Bhat, R.; Min-Tze, L.; Karim, A.A.; Mansor, S.M. Influence of sonication treatments and extraction solvents on the phenolis and antioxidants in star fruits. J. Food Sci. Technol. 2012, 49, 510-514. [CrossRef]

27. Pakash Maran, J.; Manikandan, S.; Niventha, C.V.; Dinesh, R. Ultrasound assisted extraction of bioactive compounds from Nephelium lappaceum L fruit pee using central composite face centered response surface design. Arab. J. Chem. 2017, 10 (Suppl. 1), S1145-S1157. [CrossRef]

28. Chemat, F.; Vian, M.A.; Fabiano-Tixier, A.-S.; Nutrizio, M.; Jambrak, A.R.; Munekata, P.E.S.; Lorenzo, J.M.; Barba, F.J.; Binello, A.; Cravotto, G. A review of sustainable and intensified techniques for extraction of food and natural products. Green Chem. 2020, 22, 2325-2353. [CrossRef]

29. Shahidi, F.; Zhong, Y. Measurement of antioxidant activity. J. Funct. Foods 2015, 18, 757-781. [CrossRef]

30. Siebert, K.J. Haze formation in beverages. LWT 2006, 39, 987-994. [CrossRef]

31. Hagerman, A.E.; Butler, L.G. Protein precipitation method for the quantitative determination of tannins. J. Agric. Food Chem. 1978, 26, 809-812. [CrossRef]

32. Oudane, B.; Boudemagh, D.; Bounekhel, M.; Sobhi, W.; Vidal, M.; Broussy, S. Isolation, characterization, antioxidant activity, and protein-precipitating capacity of the hydrolyzable tannin punicalagin from pomegranate yellow peel Punica granatum. J. Mol. Struct. 2018, 1156, 390-396. [CrossRef]

33. Woinaroschy, A.; Badarau, C.; Brezan, B. The total content of polyphenols and flavonoids of some plants extracts, as potential additions for cider obtaining. UPB Scientific Bulletin Series B 2019, 81, 23-30.

34. Brezan., B. Studies Relating to the Quality of the Cider-Food Product Obtained by Fermentation. Research on the Influence of New Added (Natural Aroma, Comestible Flowers) for Quality Indicators to Different Cider Variants Prepared in Laboratory. Bachelor's Thesis, Danubius University of Galati, Galați, Romania, 2013.

35. Singleton, V.L.; Orthofer, R.; Lamuela-Raventos, R.M. Analysis of total phenols and other oxidation substrates and antioxidants by means of Folin-Ciocalteu reagent. Methods Enzymol. 1999, 299, 152-178. [CrossRef] 
36. Jayanty, S.S. Comparison of Polyphenol Content and Antioxidant Capacity of Colored Potato Tubers, Pomegranate and Blueberries. J. Food Process. Technol. 2014, 5, 1-7. [CrossRef]

37. Badarau, C.L.; Stefan, M.F.; Tican, A. Comparative Analysis Of Total Polyphenol Content, Total Flavonoid Content And Antioxidant Potential Of Four Colored Flesh Potato Genotypes And Some Berries Fruits. IJERA 2018, 8, 74-80.

38. Benzie, I.; Strain, J. The Ferric Reducing Ability of Plasma (FRAP) as a Measure of "Antioxidant Power": The FRAP Assay. Anal. Biochem. 1996, 239, 70-76. [CrossRef] [PubMed]

39. Erel, O. A novel automated direct measurement method for total antioxidant capacity using a new generation, more stable ABTS radical cation. Clin. Biochem. 2004, 37, 277-285. [CrossRef] [PubMed]

40. Rel Assay Diagnostics, Research \& Clinical Chemistry Assay Kits, Gaziantep, Turkey. Available online: www.relassay.com (accessed on 7 April 2020).

41. Jolicoeur, C. The New Cider Maker's Handbook: A Comprehensive Guide for Craft Producers; Chelsea Green Publishing: Chelsea, VT, USA, 2013; pp. 51-94.

42. Lieu, L.N.; Le, V.V.M. Application of ultrasound in grape mash treatment in juice processing. Ultrason. Sonochem. 2010, 17, 273-279. [CrossRef]

43. Adekunte, A.; Tiwari, B.; Scannell, A.; Cullen, P.J.; O'Donnell, C. Modelling of yeast inactivation in sonicated tomato juice. Int. J. Food Microbiol. 2010, 137, 116-120. [CrossRef] [PubMed]

44. Bhat, R.; Kamaruddin, N.S.B.C.; Min-Tze, L.; Karim, A.A. Sonication improves kasturi lime (Citrus microcarpa) juice quality. Ultrason. Sonochem. 2011, 18, 1295-1300. [CrossRef] [PubMed]

45. Escarpa, A.; González, M. Approach to the content of total extractable phenolic compounds from different food samples by comparison of chromatographic and spectrophotometric methods. Anal. Chim. Acta 2001, 427, 119-127. [CrossRef]

46. Mason, T.J. The uses of ultrasound in food technology. Ultrason. Sonochem. 1996, 3, S253-S260. [CrossRef]

47. Cheng, L.; Soh, C.; Liew, S.; Teh, F. Effects of sonication and carbonation on guava juice quality. Food Chem. 2007, 104, 1396-1401. [CrossRef]

48. Beveridge, T.; Tait, V. Structure and composition of apple juice haze. Food Struct. 1993, 12, 195-198.

49. Beveridge, T.; Wrolstad, R.E. Haze and cloud in apple juices. Crit. Rev. Food Sci. Nutr. 1997, 37, 75-91. [CrossRef]

50. Siebert, K.J. Effects of protein-polyphenol interactions on beverage haze, stabilization, and analysis. J. Agric. Food Chem. 1999, 47, 353-362. [CrossRef]

51. Siebert, K.J. Chapter 2 Haze in Beverages. Adv. Food Nutr. Res. 2009, 57, 53-86. [CrossRef] [PubMed]

52. Millet, M.; Poupard, P.; Le Quéré, J.-M.; Bauduin, R.; Guyot, S. Haze in Apple-Based Beverages: Detailed Polyphenol, Polysaccharide, Protein, and Mineral Compositions. J. Agric. Food Chem. 2017, 65, 6404-6414. [CrossRef] [PubMed]

53. Millet, M.; Poupard, P.; Guilois-Dubois, S.; Zanchi, D.; Guyot, S. Self-aggregation of oxidized procyanidins contributes to the formation of heat-reversible haze in apple-based liqueur wine. Food Chem. 2019, 276, 797-805. [CrossRef] [PubMed]

54. Picinelli, L.A.; Diñeiro, G.Y.; Mangas-Sanchez, J.; Rodriguez, M.R.; Suarez, V.B. Phenolic and antioxidant composition of cider. J. Food Compos. Anal. 2009, 22, 644-648. [CrossRef]

55. Pellegrini, N.; Serafini, M.; Colombi, B.; Del Rio, D.; Salvatore, S.; Bianchi, M.; Brighenti, F. Total antioxidant capacity of plant foods, beverages and oils consumed in Italy assessed by three different in vitro assays. J. Nutr. 2003, 133, 2812-2819. [CrossRef] [PubMed]

56. Saura-Calixto, F.; Goñi, I. Antioxidant capacity of the Spanish Mediterranean diet. Food Chem. 2006, 94, 442-447. [CrossRef]

57. Landrault, N.; Poucheret, P.; Ravel, P.; Gasc, F.; Cros, G.; Teissedre, P.-L. Antioxidant capacities and phenolics levels of French wines from different varieties and vintages. J. Agric. Food Chem. 2001, 49, 3341-3348. [CrossRef]

58. Villaño, D.; Fernández-Pachón, M.-S.; Troncoso, A.M.; García-Parrilla, M.C. The antioxidant activity of wines determined by the ABTS+ method: Influence of sample dilution and time. Talanta 2004, 64, 501-509. [CrossRef]

59. Zhao, H.; Chen, W.; Lu, J.; Zhao, M. Phenolic profiles and antioxidant activities of commercial beers. Food Chem. 2010, 119, 1150-1158. [CrossRef] 
60. Schwarz, M.; Rodríguez, M.S.; Martínez, C.; Bosquet, V.; Guillén, D.; Barroso, C.G. Antioxidant activity of Brandy de Jerez and other aged distillates, and correlation with their polyphenolic content. Food Chem. 2009, 116, 29-33. [CrossRef]

61. Parras, P.; Martínez-Tomé, M.; Jiménez, A.; Murcia, M.A. Antioxidant capacity of coffees of several origins brewed following three different procedures. Food Chem. 2007, 102, 582-592. [CrossRef]

62. Almajano, M.P.; Carbo, R.; Jiménez, J.A.L.; Gordon, M.H. Antioxidant and antimicrobial activities of tea infusions. Food Chem. 2008, 108, 55-63. [CrossRef]

63. Rapisarda, P.; Tomaino, A.; Cascio, R.L.; Bonina, F.; De Pasquale, A.; Saija, A. Antioxidant effectiveness as influenced by phenolic content of fresh orange juices. J. Agric. Food Chem. 1999, 47, 4718-4723. [CrossRef]

64. Nayak, C.A.; Rastogi, N.K. Optimization of solid-liquid extraction of phytochemicals from Garcinia indica Choisy by response surface methodology. Food Res. Int. 2013, 50, 550-556. [CrossRef]

(C) 2020 by the authors. Licensee MDPI, Basel, Switzerland. This article is an open access article distributed under the terms and conditions of the Creative Commons Attribution (CC BY) license (http://creativecommons.org/licenses/by/4.0/). 